\title{
EGFR expression in patients with stage III colorectal cancer after adjuvant chemotherapy and on cancer cell function
}

\author{
Ching-Wen Huang1,2,3, Yi-Ting Chen ${ }^{3,4,5}$, Hsiang-Lin Tsai, ${ }^{1,2}$ Yung-Sung Yeh ${ }^{1,6,7}$, \\ Wei-Chih Su ${ }^{1,2,6}$, Cheng-Jen Ma ${ }^{1,8}$, Tsen-Ni Tsai ${ }^{1}$ and Jaw-Yuan Wang ${ }^{1,2,6,9,10,11}$ \\ ${ }^{1}$ Division of Colorectal Surgery, Department of Surgery, Kaohsiung Medical University Hospital, Kaohsiung Medical University, \\ Kaohsiung, Taiwan \\ ${ }^{2}$ Department of Surgery, Faculty of Medicine, College of Medicine, Kaohsiung Medical University, Kaohsiung, Taiwan \\ ${ }^{3}$ Graduate Institute of Medicine, College of Medicine, Kaohsiung Medical University, Kaohsiung, Taiwan \\ ${ }^{4}$ Department of Pathology, Kaohsiung Medical University Hospital, Kaohsiung Medical University, Kaohsiung, Taiwan \\ ${ }^{5}$ Department of Pathology, Faculty of Medicine, College of Medicine, Kaohsiung Medical University, Kaohsiung, Taiwan \\ ${ }^{6}$ Graduate Institute of Clinical Medicine, College of Medicine, Kaohsiung Medical University, Kaohsiung, Taiwan \\ ${ }^{7}$ Division of Trauma and Surgical Critical Care, Department of Surgery, Kaohsiung Medical University Hospital, Kaohsiung \\ Medical University, Kaohsiung, Taiwan \\ ${ }^{8}$ Division of General and Digestive Surgery, Department of Surgery, Kaohsiung Medical University Hospital, Kaohsiung \\ Medical University, Kaohsiung, Taiwan \\ ${ }^{9}$ Center for Biomarkers and Biotech Drugs, College of Medicine, Kaohsiung Medical University, Kaohsiung, Taiwan \\ ${ }^{10}$ Research Center for Environmental Medicine, College of Medicine, Kaohsiung Medical University, Kaohsiung, Taiwan \\ ${ }^{11}$ Research Center for Natural Products and Drug Development, Kaohsiung Medical University, Kaohsiung, Taiwan \\ Correspondence to: Jaw-Yuan Wang, email: cy614112@ms14.hinet.net, jawyuanwang@gmail.com \\ Keywords: epidermal growth factor receptor; prognostic value; stage III colorectal cancer; postoperative carcinoembryonic antigen \\ Received: August 14, $2017 \quad$ Accepted: November 14, $2017 \quad$ Published: December 09, 2017
}

Copyright: Huang et al. This is an open-access article distributed under the terms of the Creative Commons Attribution License 3.0 (CC BY 3.0), which permits unrestricted use, distribution, and reproduction in any medium, provided the original author and source are credited.

\section{ABSTRACT}

The epidermal growth factor receptor (EGFR)/RAS/RAF/MEK/MAPK pathway plays a crucial role in the carcinogenesis, invasion and metastasis of colorectal cancer (CRC). However, its role in the prognosis and prediction of relapse in patients with stage III CRC after adjuvant chemotherapy remains controversial. In the present study, the clinicopathological features of 173 patients with stage III CRC who underwent radical resection and adjuvant chemotherapy with the fluoropyrimidine/folinic acid, and oxaliplatin (FOLFOX) regimen, and their prognostic values of EGFR expression were retrospectively analyzed. By conducting an in vitro CRC cell line study through the knockdown of EGFR expression, we analyzed cell proliferation, colony formation and migration. Positive EGFR expression and an abnormal postoperative serum carcinoembryonic antigen (CEA) level were found to be significant independent negative predictive factors for postoperative relapse. Furthermore, positive EGFR expression was a significant independent negative prognostic factor for disease-free survival (DFS) and overall survival (OS). Additionally, an in vitro cell line study showed that the knockdown of EGFR expression significantly reduced CRC cell proliferation, colony formation and migration. The results of in vitro and in vivo experiments demonstrated that EGFR expression had a prognostic value for OS and DFS, as well as predictive roles for postoperative relapse, in patients with stage III CRC. By analyzing both EGFR expression and the postoperative CEA, the patients with stage III CRC who were at a high risk of postoperative relapse, or mortality following adjuvant chemotherapy could be identified. In short, CRC cells with EGFR expression would exhibit a highly malignant behavior. 


\section{INTRODUCTION}

Colorectal cancer (CRC) is the third most common cancer and the third leading cause of cancer death in the United States where an estimated 135,430 newly diagnosed cases of CRC and an estimated 50,260 cancer deaths due to CRC were reported in 2017 [1]. In Taiwan, $\mathrm{CRC}$ is the most common type of cancer; its prevalence has increased rapidly, and it has been the third leading cause of cancer-related death since 2015 . The incidence of CRC was 36.44 per 100,000 (8238 newly diagnosed CRC cases) in 2000 and 44.32 per 100,000 (15764 newly diagnosed CRC cases) in 2014 [2]. In total, 5687 people in Taiwan died due to CRC in 2015. The death rate was 24.2 per 100,000 in 2015 and 18.1 per 100,000 in 2005 [2]. Nevertheless, the prognosis of patients with CRC has improved in the past decade due to the development of standard chemotherapy combinations, including fluoropyrimidine/folinic acid, irinotecan (FOLFIRI), and oxaliplatin (FOLFOX), and the progress of radiological imaging studies, and surgical treatments. In Taiwan, the 5-year overall survival (OS) for stage I, II, III, and IV CRC were $80.9 \%, 71.2 \%, 59.9 \%$, and $12.3 \%$, respectively, in 2013 [2]. Yang et al. [3] reported that the 5-year OS rates for stage I and II, III, and IV CRC were $80 \%-90 \%, 60 \%$, and $8 \%$, respectively. Patients with locally advanced CRC who underwent adjuvant chemotherapy had a 5-year disease free survival (DFS) of $73.3 \%$ [4]. CRC is a heterogenous disease, which means that its clinicopathological features and the conventional tumor-node-metastasis (TNM) staging system can not reflect its real prognosis. Therefore, the identification of molecular markers that can predict the progress, relapse, and metastasis of CRC is necessary.

Epidermal growth factor (EGF) receptor (EGFR) is a 170-KDa transmembrane receptor with an intracellular tyrosine kinase domain. EGFR is a member of the erythroblastic leukemia viral oncogene homolog receptor family. After the biding of EFGR to EGF, EFGR forms a functionally active dimer (homodimer or heterodimer) that causes the phosphorylation of tyrosine kinases in the intracellular domain of EGFR. Subsequently, this phosphorylation triggers complex intracellular signals to the cytoplasm and then to the nucleus [5]. Two major downstream signaling pathways are mediated by EGFR: the RAS/RAF/MEK/MAPK pathway and the PI3K-Akt pathway. The functions of the EGFR/RAS/RAF/MEK/ MAPK pathway are associated with gene transcription, cell-cycle progression from the G1 phase to the S phase, and cell proliferation. Moreover, the EGFR/RAS/ $\mathrm{RAF} / \mathrm{MEK} / \mathrm{MAPK}$ pathway plays a critical role in the carcinogenesis, migration, invasion, and metastasis of CRC [5]. Therefore, EGFR has been used as a target of anti-EGFR treatment (cetuximab and panitumumab) and EGFR expression has been previous used as the selection method for anti-EGFR treatment. Additionally, EGFR overexpression was previously believed to be associated with more advanced disease and poor prognosis. The prognostic value of EGFR in metastatic CRC (mCRC) has been investigated extensively; however, it remains controversial [6-11], and no relevant information available regarding stage III CRC patients after adjuvant chemotherapy.

In Taiwan, the OS rates of patients with stage III CRC was $59.9 \%$. Patients with locally advanced CRC who underwent adjuvant chemotherapy had an approximately $26.7 \%$ risk of having a relapse in 5 years. In our previous study, we demonstrated that EGFR expression has a prognostic value only in patients with metachronous metastatic CRC (mCRC) [12]. Therefore, we conducted a retrospective study here to evaluate the prognostic value of EGFR expression in patients with stage III CRC following radical resection and FOLFOX adjuvant chemotherapy. In addition, a CRC cell function assay was performed to analyze the in vitro effect of EGFR.

\section{RESULTS}

\section{Characteristics of patients with stage III CRC}

The clinical and pathological characteristics of the 173 patients with stage III CRC are listed in Table 1. The mean age of the patients was 64 (range, 30-84) years of age. Additionally, 106 (61.3\%) were men and 67 (38.7\%) were women. The median follow-up duration of the patients was 51.05 (range, 6.5-97.1) months. Immunohistochemical analysis of EGFR expression was performed in all of the patients, of which 108 (62.4\%) showed positive EGFR expression.

Positive EGFR expression was more common in the men than in the women $(67.6 \%$ vs. $32.4 \%, p=0.028)$. Sixtytwo percent of the patients with positive EGFR expression developed postoperative relapse and only $32.3 \%$ of patients with negative EGFR expression developed postoperative relapse; this difference was statistically significant $(p<0.001)$. In addition, $23.1 \%$ of the patients with positive EGFR expression and only $9.2 \%$ of the patients with negative EGFR expression developed postoperative early relapse; this difference was also significant $(p=0.021)$. The mean OS of patients with positive EGFR expression was poorer than that of those with negative EGFR expression (mean \pm standard deviation [SD]: $55.58 \pm 24.45$ months vs. $42.44 \pm 21.16$ months, $p<0.001$ ). The mean DFS of patients with positive EGFR expression was poorer mean DFS than that of those with negative EGFR expression (mean \pm SD: $49.02 \pm 27.95$ months vs. $31.15 \pm 23.69$ months, $p<0.001$ ). However, age, sex, tumor size, tumor location, histological type, tumor depth, lymph node metastasis, vascular invasion, perineural invasion, and preoperative and postoperative serum carcinoembryonic antigen (CEA) levels did not significantly differ between the patients with positive and negative EGFR expression. 
Table 1: Baseline characteristics of patients with stage III colorectal cancer according to EGFR expression

\begin{tabular}{|c|c|c|c|}
\hline Characteristic & Negative EGFR expression (\%) & Positive EGFR expression (\%) & $p$ value \\
\hline $\begin{array}{l}\text { Age } \\
<65 \text { years } \\
\geq 65 \text { years }\end{array}$ & $\begin{array}{l}32(49.2) \\
33(50.8)\end{array}$ & $\begin{array}{l}65(60.2) \\
43(39.8)\end{array}$ & 0.160 \\
\hline $\begin{array}{l}\text { Gender } \\
\text { Female } \\
\text { Male }\end{array}$ & $\begin{array}{l}32(49.2) \\
33(50.8)\end{array}$ & $\begin{array}{l}35(32.4) \\
73(67.6)\end{array}$ & $0.028^{*}$ \\
\hline $\begin{array}{l}\text { Tumor size } \\
<5 \mathrm{~cm} \\
\geq 5 \mathrm{~cm}\end{array}$ & $\begin{array}{l}41(64.1) \\
23(35.9)\end{array}$ & $\begin{array}{l}68(63.0) \\
40(37.0)\end{array}$ & 0.885 \\
\hline $\begin{array}{l}\text { Tumor location } \\
\text { Right-sided colon } \\
\text { Left-sided colon }\end{array}$ & $\begin{array}{l}16(24.6) \\
49(75.4)\end{array}$ & $\begin{array}{l}30(27.8) \\
78(72.2)\end{array}$ & 0.648 \\
\hline $\begin{array}{l}\text { Tumor location } \\
\text { Colon } \\
\text { Rectum }\end{array}$ & $\begin{array}{l}56(86.2) \\
9(13.8)\end{array}$ & $\begin{array}{l}88(81.5) \\
20(18.5)\end{array}$ & 0.426 \\
\hline $\begin{array}{l}\text { Histology } \\
\text { Well } \\
\text { Moderately } \\
\text { Poorly }\end{array}$ & $\begin{array}{c}3(4.6) \\
54(83.1) \\
8(12.3)\end{array}$ & $\begin{array}{c}3(2.8) \\
90(84.1) \\
14(13.1)\end{array}$ & 0.817 \\
\hline $\begin{array}{l}\text { Tumor depth } \\
\text { T1 + T2 } \\
\mathrm{T} 3+\mathrm{T} 4\end{array}$ & $\begin{array}{l}10(15.4) \\
55(84.6)\end{array}$ & $\begin{array}{c}9(8.3) \\
99(91.7)\end{array}$ & 0.151 \\
\hline $\begin{array}{l}\text { Lymph Node metastasis } \\
\text { N1 } \\
\text { N2 }\end{array}$ & $\begin{array}{l}44(67.7) \\
21(32.3)\end{array}$ & $\begin{array}{l}73(67.6) \\
35(32.4)\end{array}$ & 0.989 \\
\hline $\begin{array}{l}\text { Vascular invasion } \\
\text { No } \\
\text { Yes }\end{array}$ & $\begin{array}{l}41(63.1) \\
24(36.9)\end{array}$ & $\begin{array}{l}74(69.2) \\
33(30.8)\end{array}$ & 0.411 \\
\hline $\begin{array}{l}\text { Perineurial invasion } \\
\text { No } \\
\text { Yes }\end{array}$ & $\begin{array}{l}45(69.2) \\
20(30.8)\end{array}$ & $\begin{array}{l}66(61.7) \\
41(38.3)\end{array}$ & 0.316 \\
\hline $\begin{array}{l}\text { Pre-op Serum CEA }{ }^{\text {a }} \text { level } \\
<5 \mathrm{ng} / \mathrm{ml} \\
\geq 5 \mathrm{ng} / \mathrm{ml}\end{array}$ & $\begin{array}{l}36(56.3) \\
28(43.8)\end{array}$ & $\begin{array}{l}54(52.9) \\
48(47.1)\end{array}$ & 0.677 \\
\hline $\begin{array}{l}\text { Post-op Serum CEA }{ }^{\text {a }} \text { level } \\
<5 \mathrm{ng} / \mathrm{ml} \\
\geq 5 \mathrm{ng} / \mathrm{ml}\end{array}$ & $\begin{array}{l}56(87.5) \\
8(12.5)\end{array}$ & $\begin{array}{l}85(80.2) \\
21(19.8)\end{array}$ & 0.219 \\
\hline $\begin{array}{l}\text { Postoperative relapse } \\
\text { No } \\
\text { Yes }\end{array}$ & $\begin{array}{l}44(67.7) \\
21(32.3)\end{array}$ & $\begin{array}{l}41(38.0) \\
67(62.0)\end{array}$ & $<0.001^{*}$ \\
\hline $\begin{array}{l}\text { Postoperative early relapse } \\
\text { No } \\
\text { Yes }\end{array}$ & $\begin{array}{c}59(90.8) \\
6(9.2)\end{array}$ & $\begin{array}{l}83(76.9) \\
25(23.1)\end{array}$ & $0.021^{*}$ \\
\hline $\begin{array}{l}\text { Disease-free survival } \\
\text { (mean } \pm \mathbf{S D}^{\mathbf{b}} \text {, months) }\end{array}$ & $49.02 \pm 27.95$ & $31.15 \pm 23.69$ & $<0.001^{*}$ \\
\hline $\begin{array}{l}\text { Overall survival } \\
\text { (mean } \pm \mathbf{S D}^{\mathbf{b}} \text {, months) }\end{array}$ & $55.58 \pm 24.45$ & $42.44 \pm 21.16$ & $<0.001^{*}$ \\
\hline
\end{tabular}

${ }^{\mathrm{a}} \mathrm{CEA}$ : carcinoembryonic antigen; ${ }^{\mathrm{b}} \mathrm{SD}$ : standard deviation. ${ }^{*} p<0.05$. 
Table 2: Univariate and multivariate analyses of the predictive factors of postoperative relapse and postoperative early relapse in patients with stage III colorectal cancer

\begin{tabular}{|c|c|c|c|c|c|c|c|c|}
\hline \multirow{3}{*}{ Parameters } & \multicolumn{4}{|c|}{ Postoperative Relapse } & \multicolumn{4}{|c|}{ Postoperative Early Relapse } \\
\hline & \multicolumn{2}{|c|}{ Univariate analysis } & \multicolumn{2}{|c|}{ Multivariable analysis } & \multicolumn{2}{|c|}{ Univariate analysis } & \multicolumn{2}{|c|}{ Multivariable analysis } \\
\hline & $\mathrm{OR}^{\mathrm{d}}\left(95 \% \mathrm{CI}^{\mathrm{e}}\right)$ & $p$ value & $\mathrm{OR}^{\mathrm{d}}\left(95 \% \mathrm{CI}^{\mathrm{e}}\right)$ & $p$ value & $\mathrm{OR}^{\mathrm{d}}\left(95 \% \mathrm{CI}^{\mathrm{e}}\right)$ & $p$ value & $\mathrm{OR}^{\mathrm{d}}\left(95 \% \mathrm{CI}^{\mathrm{e}}\right)$ & $p$ value \\
\hline \multicolumn{9}{|l|}{ Age (years) } \\
\hline $\begin{array}{l}\geq 65 \text { vs }<65 \\
(80 / 98)\end{array}$ & $0.634(0.350-1.149)$ & 0.133 & $0.657(0.329-1.310)$ & 0.233 & $0.622(0.278-1.389)$ & 0.247 & $0.117(0.272-1.858)$ & 0.486 \\
\hline \multicolumn{9}{|l|}{ Gender } \\
\hline $\begin{array}{l}\text { Male vs Female } \\
(108 / 70)\end{array}$ & $1.099(0.602-2.005)$ & 0.759 & $0.817(0.394-1.697)$ & 0.589 & $1.219(0.544-2.730)$ & 0.63 & $0.807(0.291-1.697)$ & 0.681 \\
\hline \multicolumn{9}{|l|}{ Location } \\
\hline $\begin{array}{l}\text { Colon vs Rectum } \\
(147 / 31)\end{array}$ & $0.574(0.260-1.267)$ & 0.17 & $0.489(0.189-1.267)$ & 0.141 & $0.406(0.259-1.728)$ & 0.406 & $0.344(0.101-1.165)$ & 0.086 \\
\hline \multicolumn{9}{|l|}{ Tumor size } \\
\hline $\begin{array}{l}\geq 5 \mathrm{~cm} \text { vs }<5 \mathrm{~cm} \\
(66 / 111)\end{array}$ & $1.192(0.647-2.194)$ & 0.573 & $1.001(0.471-2.129)$ & 0.998 & $1.746(0.799-3.818)$ & 0.162 & $1.641(0.595-4.525)$ & 0.338 \\
\hline \multicolumn{9}{|l|}{ Tumor depth } \\
\hline $\begin{array}{l}\mathrm{T} 3+\mathrm{T} 4 \mathrm{vs} \\
\mathrm{T} 1+\mathrm{T} 2(158 / 20)\end{array}$ & $2.004(0.759-5.288)$ & 0.16 & $1.364(0.414-4.492)$ & 0.609 & $1.221(0.335-4.450)$ & 0.763 & $1.158(0.224-5.986)$ & 0.861 \\
\hline \multicolumn{9}{|l|}{$\begin{array}{l}\text { Lymph Node } \\
\text { metastasis }\end{array}$} \\
\hline $\begin{array}{l}\text { N2 vs N1 } \\
(57 / 121)\end{array}$ & $1.596(0.845-3.014)$ & 0.15 & $1.121(0.514-2.441)$ & 0.774 & $1.992(0.903-4.396)$ & 0.088 & $1.656(0.594-4.619)$ & 0.335 \\
\hline \multicolumn{9}{|l|}{ Histology } \\
\hline $\begin{array}{l}\mathrm{PD} \text { vs } \mathrm{MD}+\mathrm{WD}^{\mathrm{b}} \\
(22 / 155)\end{array}$ & $1.247(0.509-3.057)$ & 0.629 & $1.051(0.363-3.043)$ & 0.926 & $0.685(0.232-2.023)$ & 0.494 & $1.737(0.463-6.514)$ & 0.413 \\
\hline \multicolumn{9}{|l|}{$\begin{array}{l}\text { Vascular } \\
\text { invasion }\end{array}$} \\
\hline $\begin{array}{l}\text { Yes vs No } \\
(57 / 120)\end{array}$ & $0.842(0.448-1.583)$ & 0.593 & $0.872(0.407-1.872)$ & 0.725 & $0.689(0.287-1.651)$ & 0.403 & $0.358(0.109-1.171)$ & 0.089 \\
\hline \multicolumn{9}{|l|}{$\begin{array}{l}\text { Perineurial } \\
\text { invasion }\end{array}$} \\
\hline $\begin{array}{l}\text { Yes vs No } \\
(62 / 115)\end{array}$ & $1.325(0.713-2.462)$ & 0.374 & $0.948(0.445-2.019)$ & 0.889 & $0.861(0.377-1.966)$ & 0.722 & $0.558(0.184-1.689)$ & 0.302 \\
\hline \multicolumn{9}{|l|}{$\begin{array}{l}\text { Pre-op CEA } \\
(\mathrm{ng} / \mathrm{ml})\end{array}$} \\
\hline$\geq 5 /$ vs $<5$ (78/93) & $1.480(0.808-2.709)$ & 0.204 & $1.186(0.568-2.476)$ & 0.649 & $1.344(0.604-2.990)$ & 0.469 & $0.476(0.153-1.482)$ & 0.2 \\
\hline \multicolumn{9}{|l|}{$\begin{array}{l}\text { Post-op CEA } \\
(\mathrm{ng} / \mathrm{ml})\end{array}$} \\
\hline$\geq 5$ vs $<5(30 / 145)$ & $2.872(1.232-6.697)$ & 0.015 & $2.861(1.031-7.938)$ & 0.043 & $4.704(1.948-11.358)$ & 0.001 & $8.524(2.504-29.018)$ & 0.001 \\
\hline \multicolumn{9}{|l|}{$\begin{array}{l}\text { EGFR } \\
\text { expression }\end{array}$} \\
\hline $\begin{array}{l}\text { Positive vs } \\
\text { Negative }(108 / 65)\end{array}$ & $3.424(1.789-6.552)$ & $<0.001$ & $3.106(1.512-6.379)$ & 0.002 & $2.962(1.144-7.670)$ & 0.025 & $2.572(0.875-7.559)$ & 0.086 \\
\hline
\end{tabular}

${ }^{a}$ AJCC: American Joint Commission on Cancer; ${ }^{b} P D$ : poorly differentiated, MD: moderately differentiated, WD: well differentiated; ${ }^{\mathrm{C} C E A}$ : carcinoembryonic antigen; ${ }^{\mathrm{O} O R}$ : odd ratio; ${ }^{\mathrm{e}} \mathrm{CI}$ : confidence interval, ${ }^{*} p<0.05$.

\section{Univariate and multivariate analyses of predictive factors for postoperative relapse and postoperative early relapse of EGFR expression in patients with stage III CRC}

Univariate and multivariate analyses were performed to investigate independent predictive factors for postoperative relapse and postoperative early relapse in the patients with stage III CRC by using a logistic regression model (Table 2). On the basis of the univariate analysis of the correlation between postoperative relapse and clinicopathological features, the patients with positive EGFR expression had a 3.4-fold higher risk of postoperative relapse than did those with negative EGFR expression $(p<0.001)$. Moreover, the patients with an abnormal postoperative serum CEA level ( $\geq 5 \mathrm{ng} / \mathrm{mL}$ ) had a 2.9-fold higher risk of postoperative relapse than did those with a normal postoperative serum CEA level 
$(<5 \mathrm{ng} / \mathrm{mL})(p=0.015)$. The multivariate analysis of the correlation between postoperative relapse and clinicopathological features indicated that an abnormal postoperative serum CEA level ( $\geq 5 \mathrm{ng} / \mathrm{mL}$ ) and positive EGFR expression are independent predictive factors for postoperative relapse ( $p=0.043$; odd ratio [OR], 2.861; $95 \%$ confidence interval [CI], 1.031-7.398 and $p=0.002$; OR, 3.106; 95\% CI, 1.512-6.379, respectively, Table 2). In additional, an abnormal postoperative serum CEA level ( $\geq 5 \mathrm{ng} / \mathrm{mL}$ ) was demonstrated to be an independent prognostic factor for postoperative early relapse ( $p=0.001$; OR, 8.524; 95\% CI, 2.504-29.018, Table 2).

\section{In vitro cell line experiments}

\section{Knockdown of EGFR expression in Caco-2 cells}

Western blotting was performed to determine the protein level of EGFR in Caco-2 cells. Compared with the control group transfected with a nonspecific siRNA, EGFR expression decreased by $37.5 \%(p<0.05)$ and $70 \%(p<0.01)$ at 48 and $72 \mathrm{~h}$ after EGFR siRNA transfection, respectively. Because the siRNA-mediated downregulation of EGFR protein expression was significantly lower at $72 \mathrm{~h}$ than at $48 \mathrm{~h}$ after transfection (Figure 1A), the incubation time of $72 \mathrm{~h}$ was selected and used in subsequent experiments.

\section{Effect of EGFR knockdown on Caco-2 cells growth}

The effect of EGFR knockdown on cell proliferation was evaluated using the 3-(4,5-Dimethylthiazol-2-yl)2,5-diphenyltetrazolium bromide (MTT) assay $72 \mathrm{~h}$ after transfection. In Caco-2 cells, the downregulation of EGFR expression exerted a significant antiproliferative effect compared with the control group $(-26.4 \% ; p<0.01$; Figure $1 \mathrm{~B})$. To further evaluate the antiproliferative effect of EGFR knockdown on the growth of Caco- 2 cells, the colony formation assay was performed. The colony number of Caco- 2 cells transfected with EGFR siRNA was significantly lower than that of those transfected with a nonspecific siRNA $(-32.4 \% ; p<0.01$; Figure $1 \mathrm{C}$ and 1D). These results indicate that the knockdown of EGFR expression suppressed the proliferative ability of Caco- 2 cells.

\section{Knockdown of EGFR expression affected the migration of Caco-2 cells}

Wound healing assay was performed to examine the effects of EGFR knockdown on the migration of Caco2 cells. The images were captured in the beginning and 24 and $48 \mathrm{~h}$ after being wounded. Compared with the control group, the migration ability of Caco-2 cells transfected with EGFR siRNA was significantly inhibited at 24 and $48 \mathrm{~h}$ after being wounded ( $p<0.05$; Figure 1E).
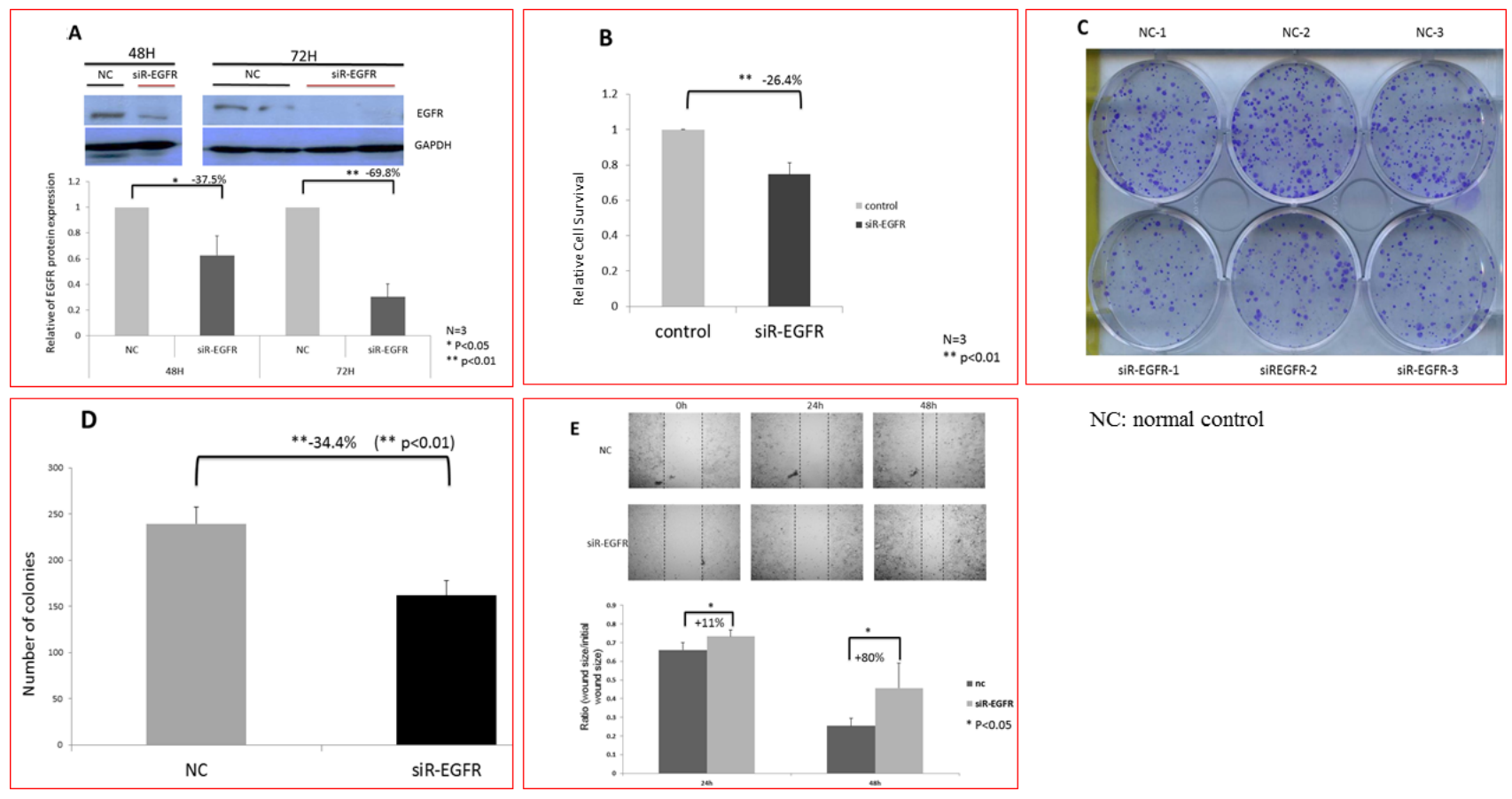

NC: normal control

Figure 1: Reduced the proliferation rate and migration ability of human cancer cells (Caco-2) caused by EGFR knockdown. (A) Western blot results showing that the expression of EGFR decreased significantly after EGFR knockdown at $48 \mathrm{~h}$ $(p<0.05)$ and $72 \mathrm{~h}(p<0.01)$. (B) The proliferation of Caco-2 cells decreased significantly after EGFR knockdown. EGFR knockdown exerted a significant antiproliferative effect $(p<0.01)$. (C and D) EGFR knockdown significantly reduced colony number of Caco-2 cells $(p<0.01)$. (E) The cell migration ability of Caco-2 cells decreased significantly after EGFR knockdown. After $48 \mathrm{~h}$ of incubation, the narrowest gap distances decreased significantly after $E G F R$ knockdown. Therefore, EGFR knockdown significantly inhibited the migration of Caco-2 cells $(p<0.05)$. 
Table 3: Univariate and multivariate analyses of the prognostic indicators for disease-free survival and overall survival in patients with stage III colorectal cancer

\begin{tabular}{|c|c|c|c|c|c|c|c|c|}
\hline \multirow{3}{*}{ Parameters } & \multicolumn{4}{|c|}{ Disease-free Survival } & \multicolumn{4}{|c|}{ Overall Survival } \\
\hline & \multicolumn{2}{|c|}{ Univariate analysis } & \multicolumn{2}{|c|}{ Multivariate analysis } & \multicolumn{2}{|c|}{ Univariate analysis } & \multicolumn{2}{|c|}{ Multivariate analysis } \\
\hline & $\mathrm{HR}^{\mathrm{d}}\left(95 \% \mathrm{CI}^{\mathrm{e}}\right)$ & $p$ value & $\mathrm{HR}^{\mathrm{d}}\left(95 \% \mathrm{CI}^{\mathrm{e}}\right)$ & $p$ value & $\mathrm{HR}^{\mathrm{d}}\left(95 \% \mathrm{CI}^{\mathrm{e}}\right)$ & $p$ value & $\mathrm{HR}^{\mathrm{d}}\left(95 \% \mathrm{CI}^{\mathrm{e}}\right)$ & $p$ value \\
\hline \multicolumn{9}{|l|}{ Age (years) } \\
\hline $\begin{array}{l}\geq 65 \text { vs }<65 \\
(80 / 98)\end{array}$ & $0.686(0.449-1.051)$ & 0.083 & $0.640(0.396-1.034)$ & 0.068 & $0.525(0.288-0.957)$ & $0.036^{*}$ & $0.594(0.305-1.157)$ & 0.126 \\
\hline \multicolumn{9}{|l|}{ Gender } \\
\hline $\begin{array}{l}\text { Male vs Female } \\
(108 / 70)\end{array}$ & $1.157(0.753-1.776)$ & 0.506 & $0.910(0.547-1.513)$ & 0.716 & $1.119(0.624-2.008)$ & 0.705 & $0.784(0.391-1.572)$ & 0.493 \\
\hline \multicolumn{9}{|l|}{ Location } \\
\hline $\begin{array}{l}\text { Colon vs Rectum } \\
(147 / 31)\end{array}$ & $0.732(0.440-1.217)$ & 0.229 & $0.682(0.366-1.270)$ & 0.228 & $1.030(0.482-2.202)$ & 0.938 & $0.867(0.349-2.153)$ & 0.759 \\
\hline \multicolumn{9}{|l|}{ Tumor size } \\
\hline $\begin{array}{l}\geq 5 \mathrm{~cm} \text { vs }<5 \mathrm{~cm} \\
(66 / 111)\end{array}$ & $1.131(0.739-1.733)$ & 0.571 & $1.099(0.662-1.824)$ & 0.716 & $1.145(0.644-2.035)$ & 0.644 & $0.791(0.397-1.578)$ & 0.506 \\
\hline \multicolumn{9}{|l|}{ Tumor depth } \\
\hline $\begin{array}{l}\mathrm{T} 3+\mathrm{T} 4 \mathrm{vs} \\
\mathrm{T} 1+\mathrm{T} 2(158 / 20)\end{array}$ & $1.703(0.786-3.689)$ & 0.177 & $1.311(0.553-3.111)$ & 0.539 & $3.364(0.816-13.861)$ & 0.093 & $2.424(0.523-11.230)$ & 0.258 \\
\hline \multicolumn{9}{|l|}{$\begin{array}{l}\text { Lymph Node } \\
\text { metastasis }\end{array}$} \\
\hline $\begin{array}{l}\text { N2 vs N1 } \\
(57 / 121)\end{array}$ & $1.497(0.973-2.303)$ & 0.067 & $1.096(0.648-1.853)$ & 0.732 & $2.086(1.182-3.682)$ & $0.011^{*}$ & $1.418(0.722-2.782)$ & 0.31 \\
\hline \multicolumn{9}{|l|}{ Histology } \\
\hline $\begin{array}{l}\mathrm{PD} \text { vs } M D+W D^{b} \\
(22 / 155)\end{array}$ & $1.357(0.737-2.499)$ & 0.326 & $1.091(0.517-2.303)$ & 0.82 & $1.639(0.767-3.503)$ & 0.202 & $1.161(0.433-3.109)$ & 0.767 \\
\hline \multicolumn{9}{|l|}{$\begin{array}{l}\text { Vascular } \\
\text { invasion }\end{array}$} \\
\hline $\begin{array}{l}\text { Yes vs No } \\
(57 / 120)\end{array}$ & $0.914(0.582-1.437)$ & 0.698 & $0.791(0.455-1.376)$ & 0.406 & $1.028(0.558-1.893)$ & 0.93 & $0.757(0.364-1.577)$ & 0.458 \\
\hline \multicolumn{9}{|l|}{$\begin{array}{l}\text { Perineurial } \\
\text { invasion }\end{array}$} \\
\hline $\begin{array}{l}\text { Yes vs No } \\
(62 / 115)\end{array}$ & $1.182(0.770-1.813)$ & 0.444 & $1.058(0.628-1.782)$ & 0.831 & $1.378(0.772-2.458)$ & 0.278 & $1.064(0.511-2.218)$ & 0.868 \\
\hline \multicolumn{9}{|l|}{$\begin{array}{l}\text { Pre-op CEA } \\
(\mathrm{ng} / \mathrm{ml})\end{array}$} \\
\hline$\geq 5 /$ vs $<5$ (78/93) & $1.282(0.833-1.971)$ & 0.259 & $0.989(0.588-1.664)$ & 0.967 & $1.114(0.616-2.012)$ & 0.721 & $0.877(0.423-1.818)$ & 0.725 \\
\hline \multicolumn{9}{|l|}{$\begin{array}{l}\text { Post-op CEA } \\
(\mathrm{ng} / \mathrm{ml})\end{array}$} \\
\hline$\geq 5$ vs $<5(30 / 145)$ & $2.430(1.482-3.985)$ & $<0.001^{*}$ & $2.649(1.414-4.964)$ & $0.002^{*}$ & $2.171(1.126-4.189)$ & $0.021^{*}$ & $2.302(0.945-5.604)$ & 0.066 \\
\hline \multicolumn{9}{|l|}{$\begin{array}{l}\text { EGFR } \\
\text { expression }\end{array}$} \\
\hline $\begin{array}{l}\text { Positive vs } \\
\text { Negative }(108 / 65)\end{array}$ & $2.615(1.595-4.285)$ & $<0.001^{*}$ & $2.485(1.443-4.281)$ & $0.001^{*}$ & $5.120(2.166-12.102)$ & $<0.001^{*}$ & 4.027 (1.625-9.977) & $0.003^{*}$ \\
\hline
\end{tabular}

a AJCC: American Joint Commission on Cancer; ${ }^{\mathrm{b} P D}$ : poorly differentiated, MD: moderately differentiated, WD: well differentiated; ${ }^{\mathrm{c}} \mathrm{CEA}$ : carcinoembryonic antigen; ${ }^{\mathrm{d} O R}$ : odd ratio; ${ }^{\mathrm{e}} \mathrm{CI}$ : confidence interval, ${ }^{*} p<0.05$.

These results indicate that the migration ability of Caco-2 cell lines decreased after EGFR knockdown.

\section{Univariate and multivariat analyses of survival of patients with stage III CRC}

Uivariate and multivariate analyses were performed to identify the independent predictive factors for OS and DFS in the patients with stage III CRC by using the Cox proportional-hazard model (Table 3). An abnormal postoperative serum CEA level was determined to be an independent negative prognostic factor for DFS ( $p=0.002$; HR, 2.649; 95\% CI, 1.031-7.938). However, the positive EGFR expression was demonstrated to be an independent negative prognostic factor for both DFS $(p=0.002$; HR, 2.485; 95\% CI, 1.443-4.281) and OS $(p=0.003$; HR, 4.027; 95\% CI, 1.625- 9.977).

A Kaplan-Meier survival analysis also indicated that patients with positive EGFR expression had significantly poorer DFS ( $p<0.001)$ and OS ( $p<0.001)$ (Figure 2A and 2B). The median DFS duration of the patients with positive and negative EGFR expression was 26.7 and 55.2 months 
$(p<0.001)$, respectively, while the median OS duration of the patients with positive and negative EGFR expression was 47.1 and 58.1 months $(p<0.001)$, respectively. Subgroup analyses based on EGFR expression and tumor location showed significant differences in terms of DFS in the patients with right- and left-sided colon cancers (Figure 2C and 2E) and in terms of OS the in patients with left-sided colon cancers (Figure 2F), but not in those with right-sided colon cancers (Figure 2D). Among the patients with right-sided colon cancers, those with positive EGFR expression had significantly poorer DFS (16.7 vs. 53.1 months, $p=0.037$ ) (Figure 2C). Additionally, patients with positive EGFR expression showed a trend of poorer OS than did those with negative EGFR expression; however, the difference was not significant (38.1 vs. 54.9 months, $p=0.061$ ) (Figure 2D). Among the patients with left-sided colon cancers, those with positive EGFR expression had significantly poorer DFS (29.6 vs. 55.7 months, $p=0.001$, Figure $2 \mathrm{E}$ ) and OS (47.7 vs. 58.4 months, $p<0.001$ ) (Figure $2 \mathrm{~F}$ ).

\section{Survival impact on postoperative relapse, postoperative early relapse, and mortality based on EGFR expression and postoperative CEA levels in patients with stage III CRC}

A univariate analysis was performed to determine predictive factors for postoperative relapse, postoperative early relapse, and mortality by combining of EGFR expression and postoperative CEA levels (Table 4). The patients with positive EGFR expression and an abnormal postoperative serum CEA level had the highest risk of postoperative relapse, postoperative early relapse, and mortality than did those with negative EGFR expression and a normal postoperative serum CEA level ( $p=0.002$; OR, 10.625; 95\% CI, 3.094-36.492 vs. $p<0.001$; OR, 11.818 ; 95\% CI, 3.127-44.663 vs. $p<0.001$; OR, 10.889; 95\% CI, 3.245-36.538, respectively).

The Kaplan-Meier survival analysis demonstrated that the patients with positive EGFR expression and an abnormal postoperative serum CEA level had significantly poorer DFS and OS than did those with negative EGFR expression or a normal postoperative serum CEA level $(p<0.001 ; p<0.001$; Figure 3A and 3B). The median DFS duration of the patients with positive EGFR expression and an abnormal postoperative serum CEA level and those with negative EGFR expression and a normal postoperative serum CEA level was 10.1 and 55.7 months, respectively. The median OS duration of patients with positive EGFR expression and an abnormal postoperative serum CEA level and those with negative EGFR expression and a normal postoperative serum CEA level was 25.6 and 58.4 months, respectively.

\section{DISCUSSION}

Of the 173 patients analyzed in this study, 108 $(62.4 \%)$ were found to have positive EGFR expression through IHC analysis. The rate of positive EGFR
A

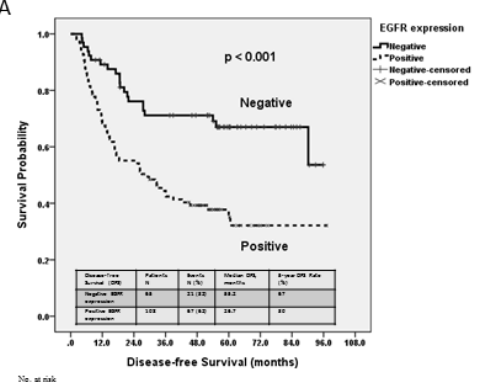

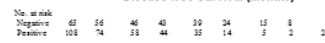

B

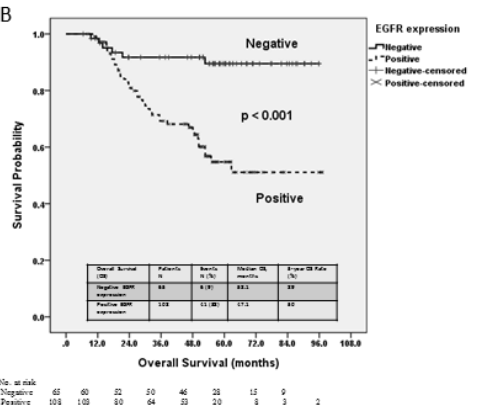

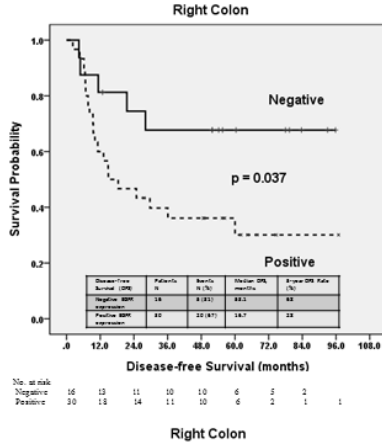

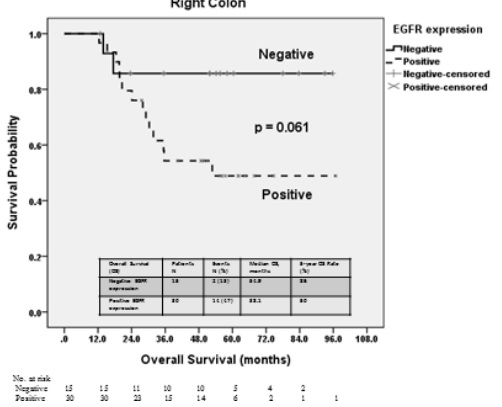

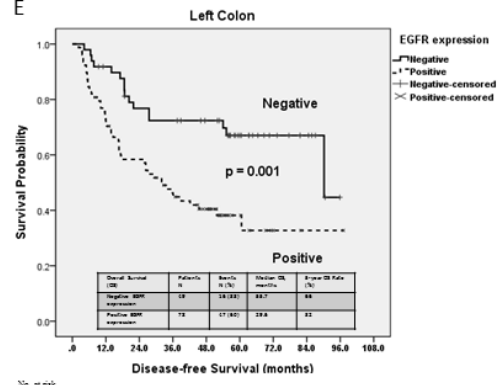

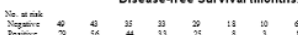

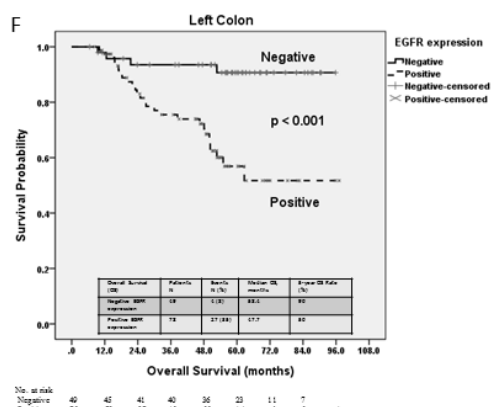

Figure 2: Kaplan-Meier survival curve for patients with stage III colorectal cancer stratified by $E G F R$ expression and tumor location. (A) Disease-free survival stratified by EGFR expression $(p<0.001)$. (B) Overall survival of patients with right-sided colon cancers stratified by EGFR expression $(p=0.037)$. (C) Disease-free survival of patients with right-sided colon cancers stratified by $E G F R$ expression $(p=0.001)$. (D) Overall survival of patients with right-sided colon cancers stratified by EGFR expression $(p<0.001)$. (E) Disease-free survival of patients with left-sided colon cancers stratified by EGFR expression $(p=0.061)$. (F) Overall survival of patients with left-sided colon cancers stratified by EGFR expression $(p<0.001)$. 
Table 4: Univariate analysis of the predictive factors for postoperative relapse, postoperative early relapse, and mortality in patients with stage III colorectal cancer based on EGFR expression and the postoperative CEA

\begin{tabular}{|c|c|c|c|c|c|c|}
\hline \multirow{2}{*}{$\begin{array}{l}\text { EGFR expression }+ \\
\text { Post-op CEA } \geq 5\end{array}$} & \multicolumn{2}{|c|}{ Postoperative Relapse } & \multicolumn{2}{|c|}{ Postoperative Early Relapse } & \multicolumn{2}{|l|}{ Mortality } \\
\hline & $\mathrm{OR}^{\mathrm{a}}\left(95 \% \mathrm{CI}^{\mathrm{b}}\right)$ & $p$ value & $\mathrm{OR}^{\mathrm{a}}\left(95 \% \mathrm{CI}^{\mathrm{b}}\right)$ & $p$ value & $\operatorname{OR}^{\mathrm{a}}\left(95 \% \mathrm{CI}^{\mathrm{b}}\right)$ & $p$ value \\
\hline Negative + No $(56)$ & 1 & & 1 & & 1 & \\
\hline Positive + No (85) & $3.243(1.577-6.670)$ & $0.001^{*}$ & $2.563(0.789-8.237)$ & 0.114 & $4.012(1.535-10.486)$ & 0.005 \\
\hline Negative + Yes $(8)$ & $2.500(0.557-11.230)$ & 0.232 & $4.333(0.651-28.860)$ & 0.13 & 0 & 0.999 \\
\hline Positive + Yes (21) & $10.625(3.094-36.492)$ & $0.002^{*}$ & $11.818(3.127-44.663)$ & $<0.001^{*}$ & $10.889(3.245-36.538)$ & $<0.001^{*}$ \\
\hline
\end{tabular}

${ }^{\mathrm{a}} \mathrm{OR}$ : odd ratio, ${ }^{\mathrm{b}} \mathrm{CI}$ : confidence interval, ${ }^{*} p<0.05$.

expression in patients with $\mathrm{CRC}$ was reported to be $25 \%-82 \%$ in one study [7]. A significantly higher proportion of the patients with positive EGFR expression in the present study developed postoperative relapse and postoperative early relapse than did those with negative EGFR expression. An abnormal postoperative serum CEA level ( $\geq 5 \mathrm{ng} / \mathrm{mL})$ and positive EGFR expression were identified to be independent negative predictive factors for postoperative relapse. Furthermore, the patients with positive EGFR expression had significantly poorer DFS and OS. After combining of EGFR Expression and postoperative serum CEA level, the patients with positive EGFR expression and an abnormal postoperative serum CEA level had a higher risk of postoperative relapse, postoperative early relapse, and mortality and poorer DFS and OS than did those with negative EGFR expression and a normal postoperative serum CEA level.
Right- and left-sided cancers are different in terms of clinicopathlogical characteristics and molecular pathogenesis [13-16]. However, in the present study, the results of the IHC analysis showed no significant differences in EGFR expression between right- and leftsided colon cancers; this finding is in accordance with those of some previous studies [17-19]. Prior research has also reported that the mRNA expression levels of EGFR does not significantly differ between right- and leftsided colon cancers [20, 21]. However, Neumann et al. [22] reported that low-grade EGFR IHC expression was significantly associated with right-sided colon cancers ( $p$ $=0.004$ ), and Shimamoto et al. [23] found that the highest mRNA expression level of EGFR occurred in patients with left-sided colon cancers. Notably, the aforementioned studies [17-23] evaluated EGFR expression in patients with either stage I-IV or IV CRC. However, in the present
A

\begin{tabular}{|c|c|c|c|c|}
\hline Overal Survival (05) & Patients, N & Events, $N[\$ 3)$ & Mesian 05, moetts & 5 -year ofs Rate [8] \\
\hline $\begin{array}{l}\text { Negztire EGFR+Post-OP } \\
\text { CAts }\end{array}$ & 36 & $16(29)$ & & 71 \\
\hline $\begin{array}{l}\text { Poiditiv IGFR + Pout-OP } \\
\text { CES }\end{array}$ & 85 & $43[56]$ & 361 & 32 \\
\hline $\begin{array}{l}\text { Negzitive EGFR+Post-OP } \\
\text { CEA }=5=5\end{array}$ & 3 & $4(50)$ & 18.6 & 48 \\
\hline 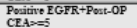 & 21 & $17 \mid(81)$ & 10.1 & 19 \\
\hline
\end{tabular}

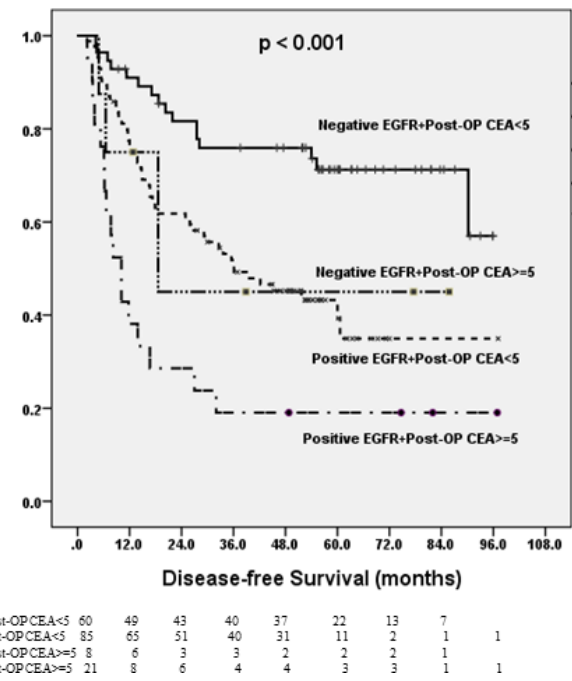

B

\begin{tabular}{|c|c|c|c|c|}
\hline Overal Sarvival (05) & Patients, $\mathrm{N}$ & Events, $N[30]$ & Mecian 05, montss & 5 year os fote [\$3) \\
\hline 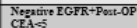 & 55 & 6[11] & 53.4 & 83 \\
\hline 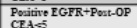 & 35 & $23(33)$ & 437 & 54 \\
\hline 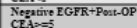 & 8 & O(0) & 4.9 & 100 \\
\hline 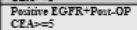 & 21 & $12(57)$ & 25.6 & \\
\hline
\end{tabular}

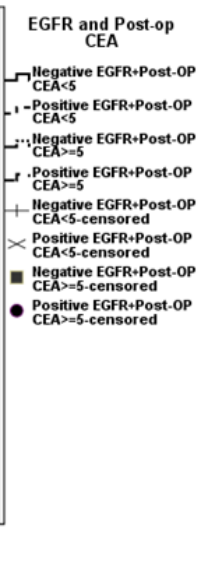

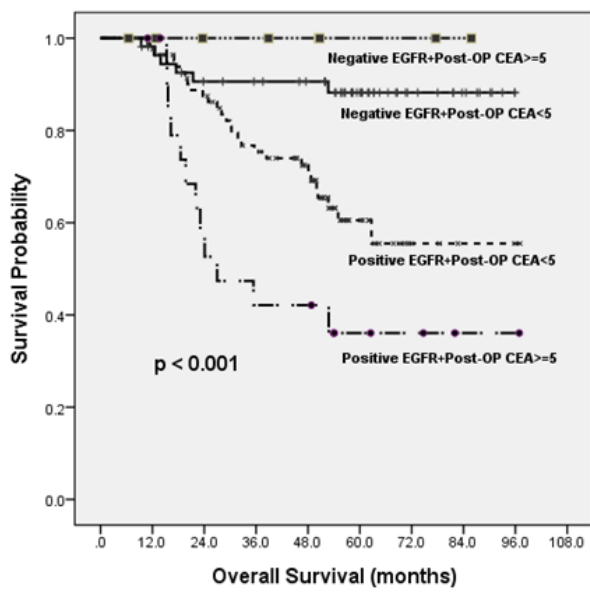

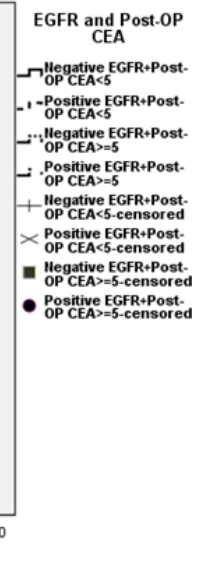

No. at risk

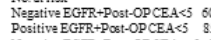

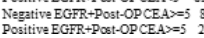

Figure 3: Kaplan-Meier survival curve for patients with stage III colorectal cancer stratified by both EGFR expression and the postoperative serum CEA level. (A) Disease-free survival $(p<0.001)$. (B) Overall survival $(p<0.001)$. 
study, we only evaluated EGFR expression in patients with stage III CRC.

The results of this study revealed that a significantly higher proportion of the patients with positive EGFR expression developed postoperative relapse and postoperative early relapse than that of those with negative EGFR expression. Moreover, positive EGFR expression was an independent predictive factor for postoperative relapse. Galizia et al. [7] reported that the risk of recurrence at 48 months was less than $20 \%$ in patients with EGFR-negative cancers and was $87 \%$ in patients with EGFR-positive cancers. Azria et al. [24] evaluated the prognostic effect of EGFR expression on locoregional recurrence in patients with stage II-III rectal cancer who underwent preoperative radiotherapy and curative surgery. They reported that the locoregional recurrence rate was higher in patients with EFGR expression $\geq 25 \%$ than in those with EFGR expression $\leq 25 \%$ (namely, $20 \%$ vs. $7 \%$ ). The locoregional recurrence-free survival rate at 2 years was $94 \%$ and $84 \%$, respectively, in these patients. Thus, EFGR extent $\geq 25 \%$ is considered to be an independent prognostic factor for locoregional recurrence. Moreover, Giralt et al. [25] reported that a significantly higher proportion of patients with positive EGFR expression developed distal recurrence than that of those with negative EGFR expression.

On the basis of the aforementioned results, we hypothesize that tumor cells with positive EGFR expression are more proliferative and have increased migration capacity compared with tumor cells with negative EGFR expression. Because the Caco- 2 cell line demonstrates wild-type KRAS gene and positive EGFR expression [26], we used it to perform in vitro cell line experiments. After transfection with EGFR siRNA, Caco2 cells exhibited less proliferative capacity in the MTT and colony formation assays. Moreover, the migration capacities of Caco-2 cell lines decreased after EGFR knockdown.

We also identified EGFR expression as an independent negative prognostic factor for OS and DFS by using the multivariate Cox proportional hazards model. The Kaplan-Meier survival analysis also demonstrated that the patients with positive EGFR expression had poorer 5 -year OS and DFS. The prognostic values of EGFR expression were evaluated in the subgroup analysis of tumor location (right- vs. left-sided colon). Although the difference in OS was not significant between the patients with right- and left-sided colon cancers, OS tended to be more favorable in the patients with negative EGFR expression than in those with positive EGFR expression. This finding may be attributed to the introduction and administration of more target agents to patients with mCRC, which can further complicate OS. Galizia et al. [27] reported a strong association between disease-specific survival and EGFR expression status, and a more than 10fold risk of cancer-related death in patients with positive
EGFR expression compared with those with negative EGFR expression. The difference was even stronger in patients with Duke's C and D colon cancer than in those with Duke's A and B colon cancer [27]. Elsewhere, Theodoropoulos et al. reported a significant association between high EGFR expression and advanced T3 and T4 stages [19], which implied that EGFR overexpression was associated with tumor invasion. Furthermore, they also demonstrated a trend between positive EGFR expression and poor OS. Rokita et al. [28] reported that EGFR overexpression was an independent adverse prognostic factor for and associated with poor OS. Lu et al. reported EGFR overexpression as a useful independent prognostic factor for recurrence and survival in 126 patients with stage I-III CRC and a significant association between EGFR overexpression and decreased 5-year OS [29].

In the present study, we found that an abnormal postoperative serum CEA level was an independent prognostic factor for postoperative relapse and postoperative early relapse, as well as an independent negative prognostic factor for DFS. Although an abnormal postoperative serum CEA level was not an independent negative prognostic factor for OS, the patients with an abnormal postoperative serum CEA level had 2.2-folds higher mortality risk than did those with a normal postoperative serum CEA level. Therefore, we evaluated predictive factors for postoperative relapse, postoperative early relapse, and mortality by combining of EGFR expression and postoperative CEA. The patients with positive EGFR expression and an abnormal postoperative serum CEA level had the highest risk of postoperative relapse, postoperative early relapse, and mortality.

The current study has some limitations. First, the present study is a single-institution retrospective study. Second, the evaluation of EGFR expression was based on IHC analysis, and the immunoreactivity of EGFR was determined by two independent pathologists. We also did not evaluate the patients' mRNA expression levels through real-time polymerase chain reaction. Nevertheless, the current study does provide some vital findings. To the best of our knowledge, this study is the first to evaluate the prognostic values of EGFR expression in patients with stage III CRC after adjuvant chemotherapy. Second, we performed in vitro experiments to verify that CRC cells with positive EGFR expression are more proliferative and have increased migration capacity compared with those with negative EGFR expression. Third, by combining of the EGFR expression and postoperative CEA level, we successfully identified the patients who have the highest risk of postoperative relapse, postoperative early relapse, and mortality.

In conclusion, we demonstrated that EGFR expression has a prognostic value of OS and DFS and predictive roles for postoperative relapse in patients with stage III CRC following radical resection and FOLFOX adjuvant chemotherapy. Our data indicate that EGFR 
expression is an independent negative prognostic factor for OS and DFS and might play a crucial role in the carcinogenesis, invasion and metastasis of CRC.

\section{MATERIALS AND METHODS}

\section{Patients}

In the retrospective study, 173 patients with histologically confirmed stage III CRC who had received surgical treatment from a single institution between January 2008 and June 2012 were included. To reduce the effect of neoadjuvant treatment on gene expression, patients were excluded if they had undergone neoadjuvant treatment with either chemotherapy or radiotherapy before surgery. All 173 patients with stage III CRC in the present study had received adjuvant chemotherapy with the FOLFOX regimen after radical surgery. The present study was approved by the institutional review board of Kaohsiung Medical University Hospital (KMUHIRB-E-20150003). Patients' clinical outcomes and survival statuses were regularly followed up. Available variables included age at diagnosis, sex, tumor location, histological type, TNM classification, vascular invasion, perineural invasion, and preoperative and postoperative serum CEA level. The TNM classification was defined according to the criteria of the American Joint Commission on Cancer/Union for International Cancer Control (AJCC/ UICC) [30]. Right-sided colon cancers were defined as those located in the cecum, ascending colon, hepatic flexure, and transverse colon, whereas left-sided cancers were defined as those located in the splenic flexure, descending colon, sigmoid, and rectum. All patients were followed until their deaths, their last follow-up, or October $31,2016$.

The development of a new local recurrence (tumor growth restricted to the anastomosis or the region of the primary operation) or distant metastatic lesions (distant metastases or diffuse peritoneal carcinomatosis) after surgery was defined as a postoperative relapse. Early relapse was defined as any local recurrence or distant metastases within past 12 months after surgery [31, 32]. OS was defined as the time from the date of primary treatment to the date of death from any cause or until the date of the last follow-up. DFS was defined as the time from the date of primary treatment to the date of diagnosis for recurrence or metastatic disease or to the date of the last follow-up.

\section{IHC analysis of EGFR expression}

Formalin-fixed and paraffin-embedded tissue blocks were cut into $3-\mu \mathrm{m}$ sections and deparaffinized, rehydrated, and autoclaved at $121^{\circ} \mathrm{C}$ for $5 \mathrm{~min}$ in Target Retrieval solution ( $\mathrm{pH}$ 6.0; Dako, Glostrup, Denmark) to retrieve antigens. Endogenous peroxidase was blocked using 3\% hydrogen peroxide for $5 \mathrm{~min}$ at room temperature. After washing with a Tris buffer solution, the sections were incubated with EGFR for $1 \mathrm{~h}$ at room temperature. Then, DAKO REAL EnVision Detection System-HRP (Dako) was applied for 30 minutes at room temperature. Finally, the sections were incubated in 3',3-diaminobenzidine for 5 minutes, before being counterstained with Mayer's hematoxylin. The sections were dehydrated through two changes of $95 \%$ ethanol and two changes of $100 \%$ ethanol, and the samples were cleared in three changes of xylene and then mounted. Negative controls were obtained by replacing the primary antibody with nonimmune serum. The immunoreactivity of EGFR was evaluated by two independent researchers who were blinded to patient s' outcomes.

The expression patterns of EGFR were determined in a semiquantitative manner through light microscopy. Immunoreactivity for EGFR (membrane staining) was categorized according to the presence of tumor cell staining and staining intensity. The intensity of EGFR immunoreactivity was scored using a three-tier system as follows [7, 33]: 1+ (weak intensity), 2+ (moderate intensity), and 3+ (strong intensity) (Figure 4). A negative EGFR expression is defined as the absence of membrane staining above the background in all tumor cells, whereas a positive EGFR expression is defined the complete or incomplete IHC membrane staining of tumor cells, including intensities of $1+, 2+$, or $3+$.

\section{In vitro cell line experiments}

\section{Cell culture and transfection}

The human colon cancer cell line Caco-2 was obtained from the American Type Culture Collection (Manassas, VA, USA). Dulbecco's modified Eagle's medium (DMEM), penicillin-streptomycin mixture, trypsin-EDTA, and fetal bovine serum (FBS) were obtained from Gibco Life Technologies (Milano, Italy). Lipofectamine 2000 was purchased from Invitrogen (Carlsbad, CA, USA). An enhanced chemiluminescence kit, EGFR siRNA (Cat\# 4390824), and nonspecific siRNA (Cat\# 439043) were purchased from Thermo Fisher Scientific (Bremen, Germany). Rabbit monoclonal antibodies against $G A P D H$ and $E G F R$ were purchased from Proteintech (Chicago, IL, USA) and Abcam (Cambridge, UK), respectively. Goat antirabbit immunoglobulin $\mathrm{G}$ was obtained from Jackson ImmunoResearch Laboratories (West Grove, PA, USA). Crystal violet and the MTT were obtained from SigmaAldrich (St. Louis, MO, USA) and VWR (VWR, West Chester, PA, USA), respectively. The Caco-2 cell line was cultured in DMEM supplemented with 10\% FBS and 1\% penicillin-streptomycin at 37 and 5\% CO2 in humidified atmosphere. The culture medium was changed every other day and the cells were subcultured using trypsin-EDTA. Prior to transfection with small interfering RNA (siRNA) 
oligonucleotides, the cells were plated in a $6-\mathrm{cm}$ dish at a density of $2 \times 10^{5}$. After incubation for $24 \mathrm{~h}$, the cells were transfected with a nonspecific siRNA or EGFR siRNA (80 nmol/L) [34] by using Lipofectamine RNAi max and OPTIMEM I medium according to the manufacturer's instruction. The transfected cells were incubated for 48 and $72 \mathrm{~h}$ prior to further studies.

\section{Western blotting}

After transfection for 48 and $72 \mathrm{~h}$ transfection, the cells were harvested and lysed in RIPA buffer ( $1 \mathrm{mM}$ EDTA, pH 8.0, $100 \mathrm{mM} \mathrm{NaCl}, 20 \mathrm{mM}$ Tris, $\mathrm{pH}$ 8.0, 0.5\% Nonidet P-40, and $0.5 \%$ Triton X-100) and quantified using a Bio-Rad kit following the manufacturer's instructions. Thirty microgram of total cell lysates was subjected to protein denaturation and sodium dodecyl sulfate-polyacrylamide gel electrophoresis. The separated proteins were electro-transferred onto polyvinylidene difluoride membranes through electroblotting for $1.5 \mathrm{~h}$ $(80 \mathrm{~V})$. Following blocking with $5 \%$ skim milk for $1 \mathrm{~h}$, the membrane was incubated with primary antibodies
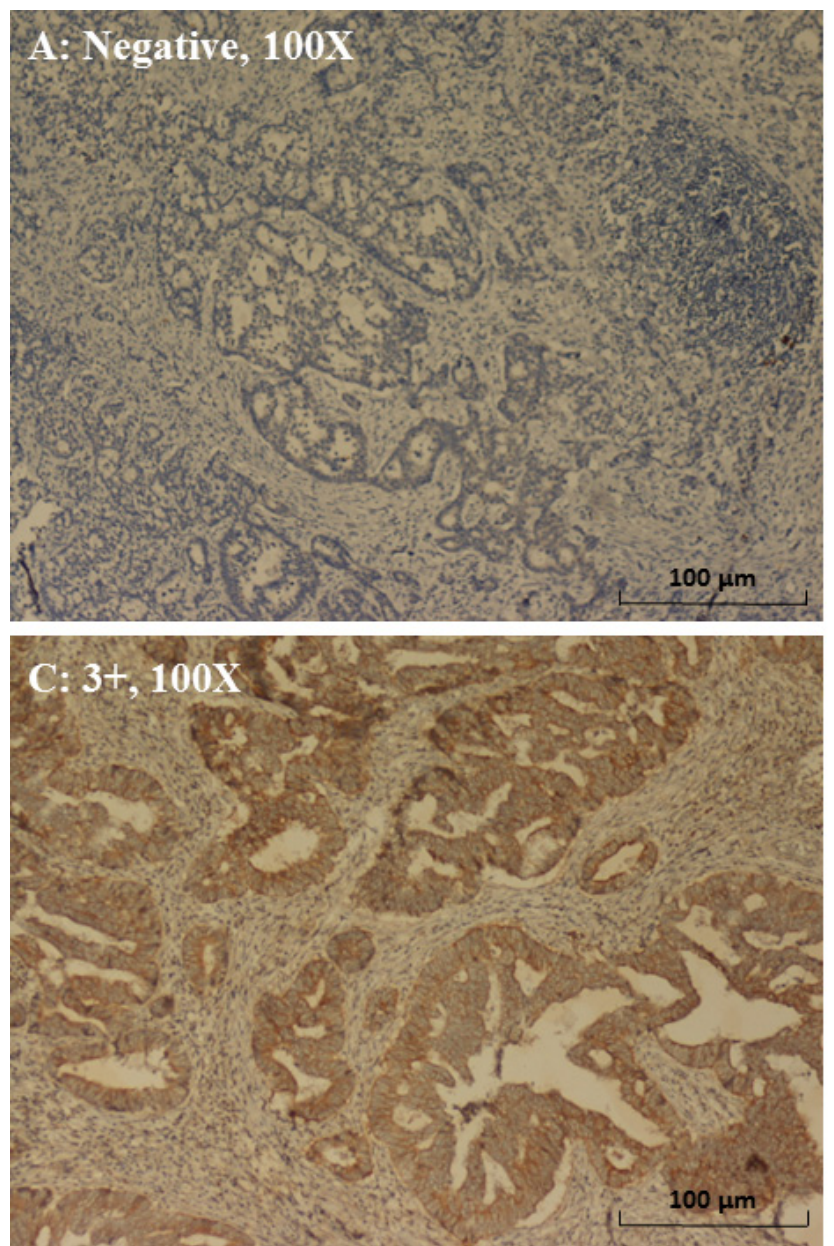

at $4^{\circ} \mathrm{C}$ overnight. After washing the membrane thrice, it was incubated with the secondary antibody at room temperature for $1 \mathrm{~h}$. Subsequently, protein bands were visualized using an enhanced chemiluminescence kit and medical X-ray films, and the relative densities were quantified.

\section{Colony formation assay}

After transfection of siRNA for $72 \mathrm{~h}$, the cells were washed, plated in 6-well plates (2000 cells /well) and incubated at $37^{\circ} \mathrm{C}$ for 10 days. Subsequently, the cells were washed with PBS, fixed with methanol, and then stained with $0.5 \%$ crystal violet. Colonies were photographed and counted using Image J software [35].

\section{MTT assay}

The transfected cells were plated in 96 wells $(1 \times 104$ cells/well $)$ and incubated at $37^{\circ} \mathrm{C}$ for $72 \mathrm{~h}$. After $72 \mathrm{~h}, 20 \mu \mathrm{L}$ of $5 \mathrm{mg} / \mathrm{mL}$ MTT was added to each well and incubated for $2 \mathrm{~h}$ at $37^{\circ} \mathrm{C}$. After removing the medium,
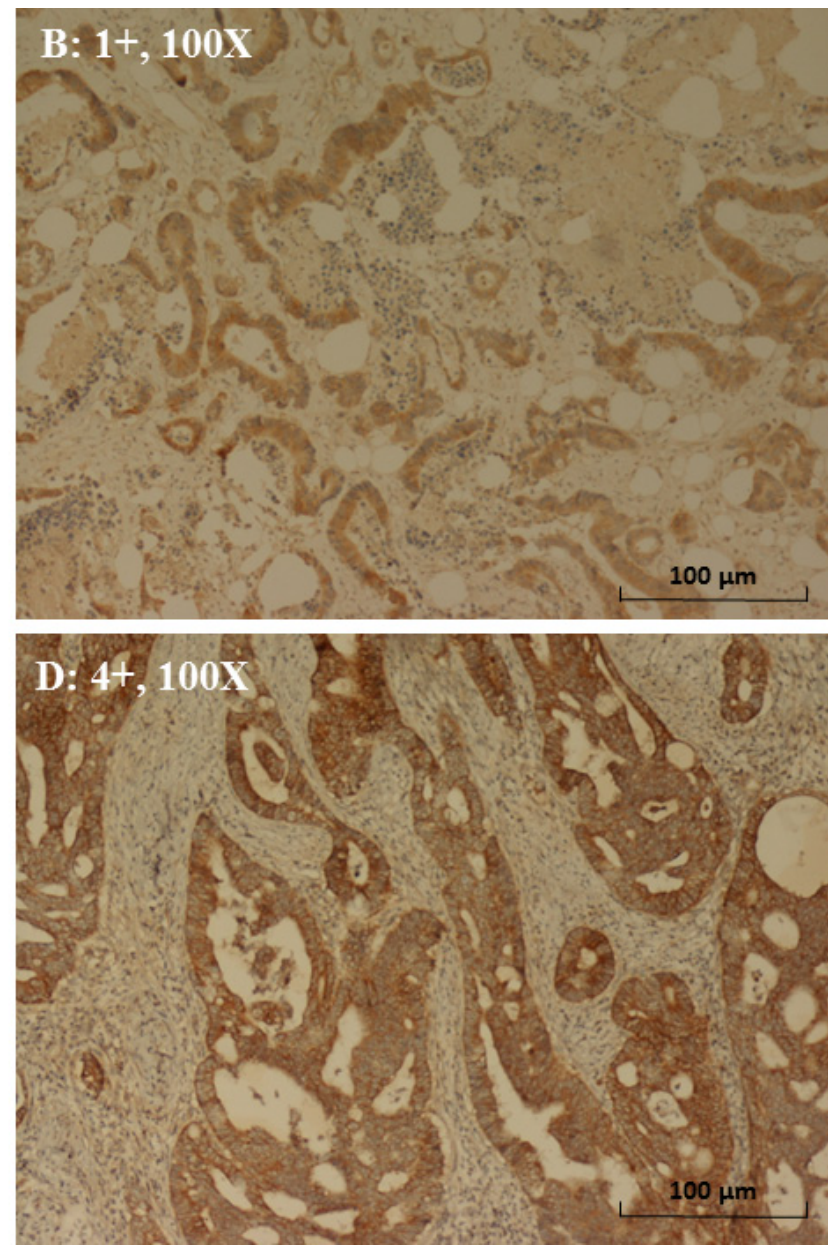

Figure 4: Immunohistochemical staining of EGFR in CRC. (A) Negative expression (magnification, 100×). (B) 1+ expression (weak intensity of membrane staining) (magnification, 100×). (C) 2+ expression (moderate intensity of membrane staining) (magnification, 100X). (D) $3+$ expression (strong intensity of membrane staining) (magnification, 100×). 
$100 \mu \mathrm{L}$ of dimethyl sulfoxide was added to the cells, and the cells were spectrophotometrically quantified by at a wavelength of $570 \mathrm{~nm}$ [36].

\section{Migration assay}

Cell migration was assessed using a wound healing assay $[37,38]$. The cells were cultured as confluent monolayers in 12-well plates and wounded using a $200 \mu \mathrm{L}$ pipette tip; the detached cells were then carefully rinsed. At 0,24 , and $48 \mathrm{~h}$ after the wounding, three pictures of each wounded area were take obtained under bright field microscope. Wound closure was measured with Image J software. Data are shown as the percentage of wound closure compared with that of the initial wound.

\section{Statistical analysis}

All data were statistically analyzed using the Statistical Package for the Social Sciences, version 22.0 (SPSS Inc., Chicago, IL, USA). The correlation between clinicopathological features and EGFR expression was examined using the Chi-square test for categorical variables and Student $t$ test for continuous variables. Univariate and multivariate logistic regression models were used to evaluate the independent predictors of postoperative relapse and postoperative early relapse. A Cox proportional hazard model was used for univariate and multivariate analyses to identify independent prognostic factors for OS and DFS. DFS and OS were evaluated using the Kaplan-Meier method, and the log-rank test was used to compare time-toevent distributions. A $p$ value less than 0.05 was considered statistically significant.

\section{Abbreviations}

AJCC: American Joint Commission on Cancer; CEA: carcinoembryonic antigen; CRC: colorectal cancer; DFS: disease-free survival; EGFR: epidermal growth factor receptor; IHC: immunohistochemical; MD: Moderately differentiated; MTT: 3-(4,5-Dimethylthiazol2-yl)-2,5-diphenyltetrazolium bromide; OS: overall survival; PD: poorly differentiated; UICC: Union for International Cancer Control; WD: well differentiated.

\section{Author contributions}

$\mathrm{CWH}$ analyzed the data and wrote the manuscript. YTC participated in making the formalinfixed and paraffin-embedded tissue blocks, the immunohistochemical staining of EGFR, and the interpretation of EGFR expression. HLT, YSY, WCS, and CJM made substantial contributions related to data acquisition, statistical analyses, and data interpretation as well as helped with manuscript preparation. TNT performed in vitro cell line experiments. JYW participated in the study design and coordination. All authors have read and approved the final manuscript.

\section{ACKNOWLEDGMENTS AND FUNDING}

This study was supported by the Excellence for Cancer Research Center Grant; through funding by the Ministry of Science and Technology (MOST1052325-B-037-001) and the Ministry of Health and Welfare (MOHW106-TDU-B-212-144007); through the health and welfare surcharge on tobacco products in Taiwan, Republic of China; and grants from Kaohsiung Medical University Hospital (KMUH105-5R26, KMUHS10601, and KMUHS10608, KMUHA10664). The study was also supported by the Kaohsiung Medical University "Aim for the Top 500 University Grant" (grant nos. KMUTP105C01, KMU-TP105C11, KMU-TP105A14, KMUDK106005, KMUS105011 and SH000113 [Give2Asia]) and the Grant of Biosignature in Colorectal Cancers, Academia Sinica, Taiwan, R.O.C. (grant no.T106-002). This manuscript was edited by Wallace Academic Editing.

\section{CONFLICTS OF INTEREST}

The authors have no potential conflicts of interest to disclose.

\section{REFERENCES}

1. Siegel RL, Miller KD, Jemal A. Cancer Statistics, 2017. CA Cancer J Clin. 2017; 67:7-30.

2. Ministry of Health and Welfare, the Executive Yuan, Republic of China. Health and Vital Statistics [http://www. mohw.gov.tw/CHT/DOS/Statistic.aspx].

3. Yang WJ, Shen XJ, Ma XX, Tan ZG, Song Y, Guo YT, Yuan M. Correlation of human epidermal growth factor receptor protein expression and colorectal cancer. World J Gastroenterol. 2015; 21:8687-8696.

4. André T, Boni C, Navarro M, Tabernero J, Hickish T, Topham C, Bonetti A, Clingan P, Bridgewater J, Rivera F, de Gramont A. Improved overall survival with oxaliplatin, fluorouracil, and leucovorin as adjuvant treatment in stage II or III colon cancer in the MOSAIC trial. J Clin Oncol. 2009; 27:3109-3116.

5. Ciardiello F, Tortora G. EGFR antagonists in cancer treatment. N Engl J Med. 2008; 358:1160-1174.

6. Ljuslinder I, Melin B, Henriksson ML, Öberg Å, Palmqvist $R$. Increased epidermal growth factor receptor expression at the invasive margin is a negative prognostic factor in colorectal cancer. Int J Cancer. 2011; 128:2031-2037.

7. Galizia G, Lieto E, Ferraraccio F, De Vita F, Castellano P, Orditura M, Imperatore V, La Mura A, La Manna G, Pinto M, Catalano G, Pignatelli C, Ciardiello F. Prognostic significance of epidermal growth factor receptor expression 
in colon cancer patients undergoing curative surgery. Ann Surg Oncol. 2006; 13:823-835.

8. Spano JP, Lagorce C, Atlan D, Milano G, Domont J, Benamouzig R, Attar A, Benichou J, Martin A, Morere JF, Raphael M, Penault-Llorca F, Breau JL, et al. Impact of EGFR expression on colorectal cancer patient prognosis and survival. Ann Oncol. 2005; 16:102-108.

9. Giralt J, de las Heras M, Cerezo L, Eraso A, Hermosilla E, Velez D, Lujan J, Espin E, Rosello J, Majó J, Benavente S, Armengol M, de Torres I; Grupo Español de Investigacion Clinica en Oncologia Radioterápica (GICOR). The expression of epidermal growth factor receptor results in a worse prognosis for patients with rectal cancer treated with preoperative radiotherapy: a multicenter, retrospective analysis. Radiother Oncol. 2005; 74:101-108.

10. Azria D, Bibeau F, Barbier N, Zouhair A, Lemanski C, Rouanet P, Ychou M, Senesse P, Ozsahin M, Pèlegrin A, Dubois JB, Thèzenas S. Prognostic impact of epidermal growth factor receptor (EGFR) expression on loco-regional recurrence after preoperative radiotherapy in rectal cancer. BMC Cancer. 2005; 20;5:62.

11. Koskensalo S, Louhimo J, Hagström J, Lundin M, Stenman UH, Haglund C. Concomitant tumor expression of EGFR and TATI/SPINK1 associates with better prognosis in colorectal cancer. PLoS One. 2013; 8:e76906.

12. Huang CW, Tsai HL, Chen YT, Huang CM, Ma CJ, Lu CY, Kuo CH, Wu DC, Chai CY, Wang JY. The prognostic values of EGFR expression and KRAS mutation in patients with synchronous or metachronous metastatic colorectal cancer. BMC Cancer. 2013; 13:599.

13. Weiss JM, Pfau PR, O'Connor ES, King J, LoConte N, Kennedy G, Smith MA. Mortality by stage for rightversus left-sided colon cancer: analysis of surveillance, epidemiology, and end results--Medicare data. J Clin Oncol. 2011; 29:4401-4409

14. Powell AG, Wallace R, McKee RF, Anderson JH, Going JJ, Edwards J, Horgan PG. The relationship between tumour site, clinicopathological characteristics and cancer-specific survival in patients undergoing surgery for colorectal cancer. Colorectal Dis. 2012; 14:1493-1499.

15. Markowitz SD, Bertagnolli MM. Molecular origins of cancer: Molecular basis of colorectal cancer. N Engl J Med. 2009; 361:2449-2460.

16. Cancer Genome Atlas Network. Comprehensive molecular characterization of human colon and rectal cancer. Nature. 2012; 487:330-337.

17. Schweiger T, Hegedüs B, Nikolowsky C, Hegedüs Z, Szirtes I, Mair R, Birner P, Döme B, Lang G, Klepetko W, Ankersmit HJ, Hoetzenecker K. EGFR, BRAF and KRAS status in patients undergoing pulmonary metastasectomy from primary colorectal carcinoma: a prospective follow-up study. Ann Surg Oncol. 2014; 21:946-954

18. Papagiorgis PC, Zizi AE, Tseleni S, Oikonomakis IN, Nikiteas NI. The pattern of epidermal growth factor receptor variation with disease progression and aggressiveness in colorectal cancer depends on tumor location. Oncol Lett. 2012; 3:1129-1135.

19. Theodoropoulos GE, Karafoka E, Papailiou JG, Stamopoulos P, Zambirinis CP, Bramis K, Panoussopoulos SG, Leandros E, Bramis J. P53 and EGFR expression in colorectal cancer: a reappraisal of 'old' tissue markers in patients with long follow-up. Anticancer Res. 2009; 29:785-791.

20. Maus MK, Hanna DL, Stephens CL, Astrow SH, Yang D, Grimminger PP, Loupakis F, Hsiang JH, Zeger G, Wakatsuki T, Barzi A, Lenz HJ. Distinct gene expression profiles of proximal and distal colorectal cancer: implications for cytotoxic and targeted therapy. Pharmacogenomics J. 2015; 15:354-362.

21. Kuramochi H, Nakamura A, Nakajima G, Kaneko Y, Araida T, Yamamoto M, Hayashi K. PTEN mRNA expression is less pronounced in left-than right-sided colon cancer: a retrospective observational study. BMC Cancer. 2016; 16:366.

22. Neumann J, Wehweck L, Maatz S, Engel J, Kirchner T, Jung A. Alterations in the EGFR pathway coincide in colorectal cancer and impact on prognosis. Virchows Arch. 2013; 463:509-523.

23. Shimamoto Y, Nukatsuka M, Takechi T, Fukushima M. Association between mRNA expression of chemotherapyrelated genes and clinicopathological features in colorectal cancer: A large-scale population analysis. Int J Mol Med. 2016; 37:319-328.

24. Azria D, Bibeau F, Barbier N, Zouhair A, Lemanski C, Rouanet P, Ychou M, Senesse P, Ozsahin M, Pèlegrin A, Dubois JB, Thèzenas S. Prognostic impact of epidermal growth factor receptor (EGFR) expression on loco-regional recurrence after preoperative radiotherapy in rectal cancer. BMC Cancer. 2005; 5:62.

25. Giralt J, de las Heras M, Cerezo L, Eraso A, Hermosilla E, Velez D, Lujan J, Espin E, Rosello J, Majó J, Benavente S, Armengol M, de Torres I; Grupo Español de Investigacion Clinica en Oncologia Radioterápica (GICOR). The expression of epidermal growth factor receptor results in a worse prognosis for patients with rectal cancer treated with preoperative radiotherapy: a multicenter, retrospective analysis. Radiother Oncol. 2005; 74:101-108.

26. Shigeta K, Hayashida T, Hoshino Y, Okabayashi K, Endo T, Ishii Y, Hasegawa H, Kitagawa Y. Expression of Epidermal Growth Factor Receptor Detected by Cetuximab Indicates Its Efficacy to Inhibit In Vitro and In Vivo Proliferation of Colorectal Cancer Cells. PLoS One. 2013; 8:e66302.

27. Galizia G, Lieto E, Ferraraccio F, De Vita F, Castellano P, Orditura M, Imperatore V, La Mura A, La Manna G, Pinto M, Catalano G, Pignatelli C, Ciardiello F. Prognostic significance of epidermal growth factor receptor expression in colon cancer patients undergoing curative surgery. Ann Surg Oncol. 2006; 13:823-835.

28. Rokita M, Stec R, Bodnar L, Charkiewicz R, Korniluk J, Smoter M, Cichowicz M, Chyczewski L, Nikliński J, 
Kozłowski W, Szczylik C. Overexpression of epidermal growth factor receptor as a prognostic factor in colorectal cancer on the basis of the Allred scoring system. Onco Targets Ther. 2013; 6:967-976.

29. Lu Y, Jingyan G, Baorong S, Peng J, Xu Y, Cai S. Expression of EGFR, Her2 predict lymph node metastasis (LNM)-associated metastasis in colorectal cancer. Cancer Biomark. 2012; 11:219-226.

30. Edge SB, Byrd DR, Compton CC, Fritz AG, Greene FL, Trotti A. AJCC cancer staging manual, 7th ed. Springer, New York. 2010.

31. Huang MY, Fang WY, Lee SC, Cheng TL, Wang JY, Lin SR. ERCC2 2251A >C genetic polymorphism was highly correlated with early relapse in high-risk stage II and stage III colorectal cancer patients: a preliminary study. BMC Cancer. 2008; 8:50.

32. Tsai HL, Cheng KI, Lu CY, Kuo CH, Ma CJ, Wu JY, Chai CY, Hsieh JS, Wang JY. Prognostic significance of depth of invasion, vascular invasion and numbers of lymph node retrievals in combination for patients with stage II colorectal cancer undergoing radical resection. J Surg Oncol. 2008; 97:383-387.

33. Scartozzi M, Bearzi I, Berardi R, Mandolesi A, Fabris G, Cascinu S. Epidermal growth factor receptor (EGFR) status in primary colorectal tumors does not correlate with EGFR expression in related metastatic sites: implications for treatment with EGFR-targeted monoclonal antibodies. J Clin Oncol. 2004; 22:4772-4778.
34. Kaulfuss S, Burfeind P, Gaedcke J, Scharf JG. Dual silencing of insulin-like growth factor-I receptor and epidermal growth factor receptor in colorectal cancer cells is associated with decreased proliferation and enhanced apoptosis. Mol Cancer Ther. 2009; 8:821-833.

35. Asbagh LA, Vazquez I, Vecchione L, Budinska E, De Vriendt V, Baietti MF, Steklov M, Jacobs B, Hoe N, Singh S, Imjeti NS, Zimmermann P, Sablina A, et al. The tyrosine phosphatase PTPRO sensitizes colon cancer cells to anti-EGFR therapy through activation of SRC-mediated EGFR signaling. Oncotarget. 2014; 5:10070-10083. http:// doi.org/10.18632/oncotarget.2458.

36. Stewart JR, O'Brian CA. Resveratrol antagonizes EGFR-dependent Erk1/2 activation in human androgenindependent prostate cancer cells with associated isozymeselective PKC alpha inhibition. Invest New Drugs. 2004; 22:107-117.

37. Terc J, Hansen A, Alston L, Hirota SA. Pregnane X receptor agonists enhance intestinal epithelial wound healing and repair of the intestinal barrier following the induction of experimental colitis. Eur J Pharm Sci. 2014; 55:12-19.

38. Gross I, Duluc I, Benameur T, Calon A, Martin E, Brabletz T, Kedinger M, Domon-Dell C, Freund JN. The intestinespecific homeobox gene $\mathrm{Cdx} 2$ decreases mobility and antagonizes dissemination of colon cancer cells. Oncogene. 2008; 27:107-115. 